\title{
REDEFINITION OF NAFKAH IN THE PATTERN OF CHILD PROTECTION AND THE FORMATION OF FAMILY PROBLEMS IN INDONESIA
}

\author{
M. Nur Syafiuddin \\ Student of the Doctor of Law Science Program \\ Faculty of Law, University of Brawijaya Malang, Indonesia \\ Email: syafiuddinyustisia76@gmail.com \\ Rachmad Safa'at \\ Faculty of Law, University of Brawijaya Malang, Indonesia \\ Email: rachmad.syafaat@ub.ac.id \\ Prija Djatmika \\ Faculty of Law, University of Brawijaya Malang, Indonesia \\ Email: prija.djatmika@ub.ac.id \\ Istislam \\ Faculty of Law, University of Brawijaya Malang, Indonesia \\ Email: istislam@ub.ac.id
}

\begin{abstract}
As the most beautiful gift as well as the mandate of Allah SWT. as well as considering the child's position in family, community and state life, children must get the best protection in their development process, including through granting children's rights to a living. Several laws and regulations in Indonesia define a living as meeting the material needs of children. Such a definition raises various problems in the pattern of child protection and the formation of the benefit of families in Indonesia. This study aims to describe the redefinition of livelihoods in child protection efforts and the formation of the benefit of families in Indonesia. This research method uses normative legal research with a philosophical and statutory approach and uses a prescriptive analytic method. The results show that in the pattern of child protection and the formation of family welfare in Indonesia, children's livelihoods must be defined as meeting children's material needs so that children can survive and as fulfilling children's immaterial needs so that children can improve their quality of life.
\end{abstract}

Keywords: nafkah, family, children, Indonesia, redefinition.

\section{A. INTRODUCTION}

Children are the most beautiful gift as well as a mandate (entrusted) given to Allah SWT. to every parent. Children have a good position in the sphere of family, community and state life. In the sphere of family life, children have the position of a charitable investment value for parents whose rewards flow unceasingly, besides functioning as a successor to the struggle of parents, preserving offspring and so on. In social life, children have values in various perspectives, including religion, economics, and socio-psychology. Whereas in the scope of state life, children have a role as the successor to the ideals of the nation in the development relay, therefore children have a strategic role in ensuring the existence of a nation and state. 
The importance of the child's position, the law always requires that children be raised appropriately and responsibly to create a godly and quality generation, including through the fulfillment of children's rights so that children can grow and develop into children who have good morals, are physically and spiritually healthy and have high intelligence. . Efforts to make children grow and develop properly and correctly include ensuring the fulfillment of children's rights. Islam details more about children's rights and always reminds explicitly of the obligation of parents and society to pay attention to and fulfill children's rights, both before and after birth (Syafiyarrahman, 2002).

The attention of Islam and positive law in Indonesia to the fulfillment of children's rights is intended to ensure the growth and development of children to become perfect human beings (Kartono, 1995). Among the rights of children that must receive the main attention of parents is the right to support. In the effort to protect children, living is part of the basic rights of children that must be fulfilled in the implementation of child protection as referred to in the provisions of Law Number 23 Year 2002 concerning Child Protection as amended by Law Number 35 Year 2014 and Law Number 17 Year 2016. Islam also places the living as one of the basic rights of children among other basic rights of children, namely the rights of lineage, rights of rada'ah, rights of hadanah and rights of living. (Zahrah, 1957). In an effort to create the benefit of the family, the support of children is one of the elements in realizing the benefit of the family in Indonesia.

The majority of children's livelihoods in various statutory regulations in Indonesia are not clearly defined. As a result, in several studies on livelihoods, there are many studies that are only defined from a narrow perspective by examining income in only focused areas. In the area of family law, for example, term wages are defined as expenses to meet the needs of family clothing, food and housing. Likewise in the case of a lawsuit for child support, in several decisions that were the object of this study, 82 (eighty two) percent of cases defined a living as a material fulfillment for the child, so that when the child's material needs were met by other parties, the father tended to ignore the child's income which is the obligation.

The understanding of child support, which is only defined as meeting the material needs of children, raises various problems including philosophical problems, namely the income that is defined as the fulfillment of children's material needs cannot accommodate children's interests in child protection and the formation of family benefits as the law stipulates the obligation to fulfill children's livelihoods. Behind the provision of material livelihoods to children, there is a essence of love that is no less important for children in the process of growth and development. The juridical problem, namely the absence of statutory norms that explicitly regulate the definition of child support has an impact on legal uncertainty about the types of rights to support that must be fulfilled in the process of child development. The sociological problem is that the principle of benefit is not achieved in fulfilling children's livelihoods as outlined by the law, namely forming children so that they can grow and develop into children who have good morals, are physically and mentally healthy and have high intelligence.

Various studies on child livelihoods and protection have been carried out by many previous researchers, including research by Heti Kurnani which raised the thoughts of $A$. Hamid Sorong with the results of research that living is the main obligation of fathers in child protection (Kurnaini, 2017), This research has the advantage that the father's negligence 
on income can be sued in court. M. Abdul Fatah Santoso research suggests that the rights of children that must be fulfilled can be categorized into three, namely social, educational and financial rights. (Santoso, 2017), The advantage of this research is that it provides solutions to the fulfillment of children's rights through child-friendly education. Then the research of Muhammad Tahir and Stephan Larmar with the results that the importance of religious values in guarding children's growth and development (Tahir dan Larmar, 2020), The advantage of this research is that it emphasizes the importance of religious values in child protection efforts. Furthermore, M. Nur Syafiuddin's research states that the meaning of living in the pattern of child protection has two meanings, namely as a guarantee for child welfare and as a futuristic value in child protection. (Syafiuddin, 2021). The weakness of the four studies is that they do not discuss in depth the definition of child support in the pattern of child protection and the formation of family welfare.

Based on the background of the above problems, the theme of redefining children's livelihoods is very important to be studied, therefore the researcher conducted a study with the title "Redefinition of Children's Livelihoods in Child Protection Patterns and the Establishment of Family Benefits".

\section{B. METHOD}

This research is a normative legal research, with a philosophical, statutory and case approach. Sources of legal materials used in this study are primary, secondary and tertiary sources of legal materials. The technique of collecting legal materials is carried out using literature studies, both for materials in the form of statutory regulations, decisions and other sources of legal materials. The analysis technique used to process legal materials is through prescriptive analytical methods, hermenautics (interpretation) of law and ijtihadi. The three methods are expected to obtain research results with a deep ecology paradigm, namely legal construction based on wisdom that is able to translate and operationalize law in depth. (Safa'at, 2016).

\section{Theoretical Framework}

\section{Definition of Child's Livelihood}

Etymologically, the word nafkah is absorbed into Indonesian from Arabic, namely annafaqah, which comes from the syllable anfaqa-yunfiqu-infaqan, which means al-mashruf wa al-infaq, namely shopping costs, spending money, and living expenses. (Maluf, 1986). In terminology, livelihood is defined as spending, which means something that is given by a husband to his wife, a father to his children and relatives of his property as basic necessities for them (Departemen Agama, 1985).

Sayyid Sabiq defines a living as the needs of the person for whom he is responsible in the form of food, clothing and shelter (Sabiq, 2012). In line with this definition, Wahbah alZuhaili defines a living is sufficient to meet the needs of the dependents in the form of food, clothing and a place to live. (Al Zuhaili, 1989). Abdurrahman defines that the word nafkah has a definition as all living expenses which are the rights of the wife and children in terms of food, clothing and shelter as well as several other basic needs, even if the wife is a rich woman. (Abdurrahman, 1992). 
Based on some of the definitions of income above, operationally a child's income can be defined as a father's obligation in the form of fulfilling clothing, food and shelter as well as other needs for his biological child.

\section{Livelihoods as Children's Rights in Child Protection}

Children's rights are children's rights that are very important to be recognized and protected by law from the time the child is in the womb. Children's rights can also be defined as anything concrete and abstract that must be obtained or accepted by the child and if not obtained, the child has the right to claim these rights. In this case, those who are obliged to fulfill, guarantee and protect are parents, family, community and government.

In Indonesia, as in the provisions of Article 28B paragraph (2) of the 1945 Constitution of the Republic of Indonesia and the child protection law has outlined five basic rights of children that must be fulfilled in the process of child protection, namely the right to survival, the right to protection. , the right to growth and development, the right to participate and the right to identity.

The livelihood of children in the pattern of child protection in Indonesia is reflected in at least two basic rights, namely: first, the right to survival is the right to preserve and sustain life (the right of live) and the right to obtain the highest standard of health and the best possible care. . Second, the right to development, namely the rights of the child in the convention of children's rights which includes all forms of education (formal and nonformal) and the right to achieve a standard of living that is adequate for the child's physical, mental, spiritual, moral and social development.

\section{Position of livelihood in the formation of the benefit of the family}

There are at least four benefits in human life, namely: first, the benefit of the individual in the form of hifdzu ad-din in the context of the private-individual is to strengthen faith and perform the services that are ordered and stay away from the prohibitions of the law Second, the benefit of the family, namely the benefit can be achieved by upholding the principles of religion in the midst of family life. Third, the benefit of society, namely the social-community context of the teachings of the Shari'a which maintains the continuity of religion in the midst of society, namely the requirement of congregational prayers and amar ma'ruf nahi mungkar. Fourth, the benefit of humanity, namely by spreading the mercy of Islam throughout the world.

The Nahdlatul Ulama Family Benefit Institute as quoted by Mujiburrahman Salim formulated four characteristics of the maslahah family, namely the piety of husband and wife, good children, good associations, and sufficient sustenance. (Salim, 2019). Jamaluddin Athiyyah as a progressive figure who developed the maqashid theory, formulated that the benefits contained in family life (the benefit of the family) can be achieved through 7 efforts, namely: first, regulating the bonds between two types of humans; second, keep reproduction; third, realizing peace, hospitality and compassion (sakinah mawaddah warahmah); fourth, keep the lineage; fifth, maintaining diversity in the family; sixth, regulating the organizational side of the family; and seventh, regulating the financial side of the family (Athiyyah, 2002). 
Referring to the formulation of the characteristics of the maslahah family as formulated by the Nahdlatul Ulama Family Welfare Institute and the seven efforts to achieve the benefit of the family as formulated by Jamaluddin Athiyyah above, the researcher formulates that the elements forming the benefit of the family in Indonesia consist of five main elements. namely: elements of parental piety, abrar of children, good education and family health, good family social association and economic adequacy. The five main elements of forming the benefit of the family can be visualized in the following chart:

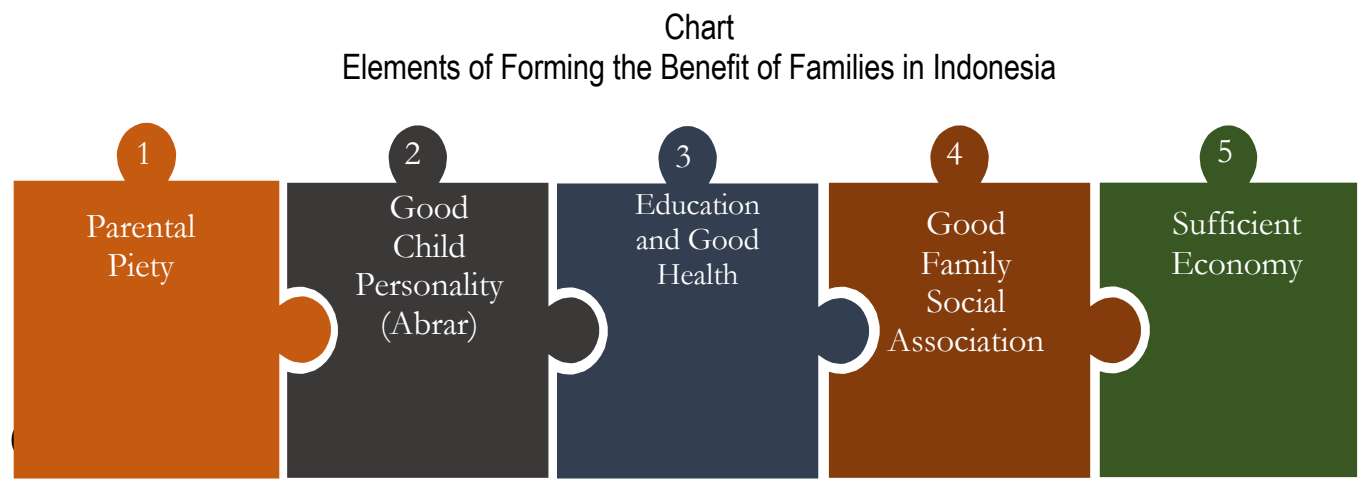

Source: author's creation

\section{Redefinition of Children's Livelihoods}

Imam Al Hafiz Al Kamal Ibn al Humam al Hanafi, defines nafaqah as providing or giving something that can make it exist and last (al Hanafi, t.t.). Researchers argue that the phrase "something that makes it happen" can be defined as a gift that is not only material to meet the needs of life but also something to improve the quality of life. Such an interpretation can lead us to the formulation of the definition of a living with "all gifts that have beneficial and material values that a husband can give to his wife, children and other family members in order to maintain life and improve the quality of life".

The Word of Allah SWT., In the Qur'an Surah Al-Baqarah Verse 233 emphasizes that giving a living must be done by ma'ruf. M. Quraish Shihab interprets the word ma'ruf in Surat Al-Baqarah Verse 233, covering the development of potential theoretical abilities, through the provision of knowledge or the development of potential amaliah through exemplary (Shihab, 2009). The interpretation of the word ma'ruf is in line with the philosophical study of income which requires individuals to maintain their productivity, which is very much determined by the education, health, community safety and social services they receive as members of the community. In the millennial era like now, livelihood must be defined as a construct of human solidarity, that humans are seen to always need each other by working together in every process of improving the quality of life. As one of the processes of development and human quality development, livelihoods are conceived as a means that are expected to be able to find a wider place to answer social problems so that their urgency is recognized by everyone and applied consequently and sustainably.

Redefinition of livelihoods, now not only revolves around meeting the needs for survival, but livelihoods also have a meaning as a means of fulfilling every need in improving the quality of life, the level of living is now oriented towards standardizing the feasibility of meeting the needs of life which can be a reference for empowering a person in the form of increasing productivity and individual skills. Thus, living in the context of family life must be defined as giving or fulfilling the needs of family members by the husband or father as the 
head of the family in accordance with their abilities (ma'ruf) which consists of the needs for survival (material) such as clothing, food and shelter, and fulfillment. the need for improving the quality of life (immaterial) such as attention, learning, affection, and others.

The perspective of the theory of al-maqashid al-sharia, the redefinition of livelihood as it is a manifestation of the purpose of establishing the law regarding hifdzu al-usrah (family protection) in Islamic legal philosophy which contains four basic values of legal determination, namely justice, mercy, benefit and wisdom. (al Jauziyyah, t.t.).

Based on the description above, the redefinition of livelihoods in the pattern of child protection and the formation of family welfare in Indonesia must be defined as: first, the fulfillment of material needs, namely the needs of children to survive such as clothing, food and shelter. Second, fulfillment of immaterial needs, namely the needs of children to be able to improve the quality of life such as attention, learning, affection, and others.

\section{Position of Livelihood in Child Protection Patterns}

One of the aspects in the pattern of child protection is the protection or fulfillment of the welfare of children, both in the family, education and social environment. The aspect of child welfare is an embodiment of the basic principles of the best interests of children and the principles of the right to life, survival and development of children.

Child welfare as in the provisions of Law Number 7 Year 1979 concerning Child Welfare is defined as an order for the child's life and livelihoods that can ensure proper growth and development, both spiritually, physically and socially. Louise Johnson and Schwartz Charles, define child welfare as community activities and programs that care and are responsible for children until they are able to care for themselves. (Johnson dan Charles, 1991). Meanwhile, children's social welfare is defined as a condition for the fulfillment of children's material, spiritual, and social needs so that they can live properly and be able to develop themselves, so that they can carry out their social functions. (Astuti, 2013).

Referring to the redefinition of livelihoods and one of the aspects in the pattern of child protection as described above, children's livelihoods contain four basic values in the pattern of child protection, namely: first, the value of justice. The main goal of child rearing is to make the child survive and improve his quality of life. Second, the value of grace. There is a side to the value of parental love for their children in providing child support, this affection is the main asset of the child to be able to grow and develop into a pious human being.

Third, the value of benefit. The physical benefits contained in the provision of material livelihood, because by providing this provision for children, their physical needs will be fulfilled (clothing, food, shelter). The spiritual benefits contained in immaterial living, with this income the children will be able to fulfill their life needs as a whole human being, compassion, mental, and others are fulfilled properly. Fourth, the value of wisdom. The wisdom behind the meaning of children's livelihood which includes material and immaterial is so that the family (read: including children) is blessed, family members become good servants, and as a form of obedience to Allah SWT. 


\section{Position of livelihood in the formation of the benefit of the family}

Referring to the redefinition of income and based on the chart of elements for the formation of family benefit above, the income has a role in realizing the four elements in the formation of family welfare, namely: first, the element of parental piety. Piety of parents can be interpreted as husband and wife who can bring benefits and benefits to themselves, their children and the surrounding environment, so that they reflect behavior and changes that can become role models (uswatun hasanah) for their children and for others. One form of exemplary behavior is the implementation of the father's obligations in fulfilling children's livelihoods.

Second, the children are good (abrar), in the sense that they are of quality, have a noble character, are healthy mentally and physically. Nafkah plays a role in shaping the quality of the child. Third, good education and health. That is, education and health of family members are guaranteed. Material livelihood is very important in supporting the guarantee of children's education and health. Fourth, having sufficient sustenance (clothing, food and shelter). That is, it does not have to be rich or abundant in wealth, the important thing is to be able to finance life and family life, from the needs of clothing, food and housing. In this case, material income is very important in ensuring the children's clothing, food and shelter needs.

From the perspective of maqasid al-sharia, the provision of child support by the biological father is a form of offspring protection (hifdh al-nasl). Jasser Audah extends the range of protection of offspring not only to the prohibition of committing adultery, but to all things that are oriented towards the benefit of the family, including protecting the rights of children, which in fact are the pillars of the future of society and the people. (Audah, 2013).

From this perspective, it is also appropriate to say that the fulfillment of children's rights to livelihoods is one of the efforts to realize the protection of offspring as part of the maqashid al-sharia child protection in the formation of family benefits, namely everything contained in maqasid al-sharia, including the protection of offspring. , then that's where the benefit is. Thus matters related to the elements of the welfare of the family - including the fulfillment of children's rights to a living - must get the main attention in an effort to realize the benefit of the family as the core of the goal in a household. Benefit in Islamic teachings is the ultimate goal in the formation of law.

\section{CONSLUSIONS}

Based on the results of the analysis and discussion above, it can be concluded that the reduction of livelihoods in the pattern of child protection and the formation of family welfare in Indonesia is the fulfillment of material and immaterial needs. First, the fulfillment of material needs, namely the needs of children to survive such as clothing, food and shelter. Second, fulfillment of immaterial needs, namely the needs of children to be able to improve the quality of life such as attention, learning, affection, and others.

\section{References}

Abdurrahman. (1992). Perkawinan dalam Syariat Islam. Rineka Cipta, Jakarta.

Al-Hanafi, Imam Al-Hafiz Al Kamal Ibn al-Humam. (t.t.). Fath al-Qodir. Dar al-Kutub, Beirut. 
Al-Jauziyah, Ibnu Qayyim. (t.t.). I'lam al-Muwaqi'in Rabb al-Alamin. Dar al-Jayl, Beirut. Al-Yasu'i, Louis Maluf. (1986). Al-Munhya' Ulumuddin. Al-Syirkiyah, Beirut.

Al-Zuhaili, Wahbah. (1989). Al-Fiqh al-Islam wa Adillatuhu. Dar al-Fikr, Beirut.

Astuti, Mulia. (2013). Kebijakan Kesejahteraan dan Perlindungan Anak. P3KS, Jakarta.

Athiyyah, Jamaluddin. (2003). Nahwa Tafil Maqashid al-Syariah. Dar al-Fikr, Damaskus Suriyah.

Audah, Jasser. (2013). al-ljtihad al-Maqasidi min al-Tashawwur al-Ushuli ila al-Tanzil alAmali. al-Syabkah al-Arabiyah li al-Abhats wa al-Nasyr, Beirut.

Departemen Agama. (1985). Ilmu Fiqh. Dirjenbinbagais, Jakarta.

Johnson, Louis and Charles, Schwartz. (1991). Social Welfare: A Response to Human Need. Allyn and Bacon, Massachusetts Boston.

Kartono, Kartini. (1995). Psikologi Anak. Mandar Maju, Bandung.

Kurnaini, Heti. (2017). Pemenuhan Hak Nafkah Anak sebagai Salah Satu Pola terhadap Perlindungan Anak: Analisis Pemikiran A. Hamid Sorong. Jurnal Kajian IImu Hukum dan Syariah, 2 (1), https://doi.org/10.22373/petita.v2i1:61.

Sabiq, Sayyid. (2012). Fikih Sunnah Jilid 2. Cakrawala Publishing, Jakarta.

Safa'at, Rachmad. (2016). Kearifan Sang Profesor Bidang Sosiologi Hukum. Surya Pena Gemilang Publishing, Malang.

Salim, Mujiburrahman. (2019). Konsep Keluraga Maslahah Perspektif Lembaga Kemaslahatan Keluarga Nahdlatul Ulama. Jurnal Pemikiran Hukum Al-Madzahib, $5(1)$.

Santoso, M. Abdul Fatah. (2017). The Rights of the Child in Islam: their Consequences for the Roles of State and Civil Society to Develop Child Friendly Education. Indonesian Journal of Islam and Muslim Societies, VII (1).

Shihab, M. Quraish. (2009). Tafsir Al-Misbah: Pesan, Kesan dan Keserasian Al-Qur'an. Lentera Hati, Jakarta.

Syafiuddin, M. Nur, et. all. (2021). Understanding Child Support in The Pattern of Child Protection Based on The Principle of Child Protection. International Journal of Multicultural and Multireligious Understanding, 8 (1), http://dx.doi.org/10.18415/ijmmu.v8i1.2260.

Syafiyarrahman, Abu Hadiyan. (2003). Hak-Hak Anak dalam Syari'at Islam. Al-Manar, Jakarta.

Tahir, Muhammad and Larmar, Stephen. (2020). Conceptualizing The Development of Personality in Children: An Analysis of Islamic Philosophy and Contemporary Western Psychology. An International Review of the Humanities and Social Sciences, 11 (1).

Zahrah, Abu. (1957). Ahwal al-Syakhsiyah. Dar al-Fikr, Kairo.

Undang-Undang Dasar Negara Republik Indonesia Tahun 1945.

Undang-Undang Nomor 7 Tahun 1989 tentang Kesejahteraan Anak.

Undang-Undang Nomor 23 Tahun 2002 tentang Perlindungan Anak sebagaimana diubah dengan Undang-Undang Nomor 35 Tahun 2014 dan Undang-Undang Nomor 17 Tahun 2016. 